\title{
Synergistic Effects of Ultrafast Heating and Gaseous Chlorine on the Neutralization of Bacterial Spores
}

Wenbo Zhou ${ }^{a}$, Mona W. Orr ${ }^{b}$, Vincent T. Lee ${ }^{b^{*}}$, Michael R. Zachariah ${ }^{a^{*}}$

${ }^{a}$ Department of Chemical and Biomolecular Engineering, and Department of Chemistry and Biochemistry, University of Maryland, College Park, MD 20742, USA

${ }^{b}$ Department of Cell Biology \& Molecular Genetics, University of Maryland, College Park, MD 20742, USA

* Corresponding authors:

Department of Chemical and Biomolecular Engineering, and Department of Chemistry and Biochemistry, University of Maryland, College Park, MD 20742, USA.

Tel: +1 3014054311 .

E-mail address: mrz@umd.edu (M.R. Zachariah).

Department of Cell Biology \& Molecular Genetics, University of Maryland, College Park, MD 20742, USA.

Tel: +1 301405 9397; fax: +1 3013141248 .

E-mail address: vtlee@umd.edu (V.T. Lee). 


\section{ABSTRACT}

Improving the neutralization of bacterial spores is of paramount importance for the bioterrorism defeat. In this study, we investigate the synergism between rapid heating $\left(\sim 10^{4}{ }^{\circ} \mathrm{C} / \mathrm{s}\right.$ to $\sim 10^{5} \mathrm{C} / \mathrm{s}$ ) and chlorine gas in the neutralization of Bacillus thuringiensis (Bt) spores - a close relative of $B$. anthracis $(\mathrm{Ba})$, which is a known biowarfare agent. Bt spores were heated in a gas chamber with defined concentrations of $\mathrm{Cl}_{2}$ gas and relative humidity $(\mathrm{RH})$. The critical peak temperature $\left(T_{c}\right)$ of spores, which corresponds to $50 \%$ reduction in viability, was decreased from

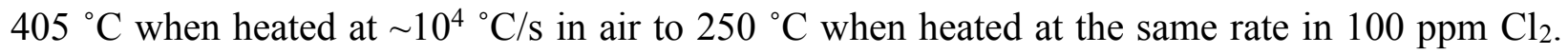
SEM results show no obvious difference between the morphologies of spores heated in air or in $\mathrm{Cl}_{2}$ at $\sim 10^{4}{ }^{\circ} \mathrm{C} / \mathrm{s}$. These results indicate that $\mathrm{Cl}_{2}$ gas acts in synergy with high temperatures $(>300$ $\left.{ }^{\circ} \mathrm{C}\right)$ to neutralize Bt spores. Similarly, the $T_{c}$ for Bt spores heated at the faster rate of $\sim 10^{5}{ }^{\circ} \mathrm{C} / \mathrm{s}$ was reduced from $230{ }^{\circ} \mathrm{C}$ when heated in air to $175^{\circ} \mathrm{C}$ when heated in $100 \mathrm{ppm} \mathrm{Cl}_{2}$. At $\sim 10^{5}{ }^{\circ} \mathrm{C} / \mathrm{s}$, the treatment of $\mathrm{Cl}_{2}$ did not alter spore morphology at temperatures below $300{ }^{\circ} \mathrm{C}$. At temperatures above $450{ }^{\circ} \mathrm{C}$ with $\mathrm{Cl}_{2}$, the spore coat detached from the underlying core. The effect of $\mathrm{Cl}_{2}$ was further examined by changing the $\mathrm{RH}$ of $\mathrm{Cl}_{2}$ gas. The results show that highly humidified $\mathrm{Cl}_{2}(\mathrm{RH}=100 \%)$ reduced $T_{c}$ by $170{ }^{\circ} \mathrm{C}$ and $70{ }^{\circ} \mathrm{C}$ at $\sim 104{ }^{\circ} \mathrm{C} / \mathrm{s}$ and $\sim 105{ }^{\circ} \mathrm{C} / \mathrm{s}$, respectively, as compared to dry $\mathrm{Cl}_{2}(\mathrm{RH}=0 \%)$. Energy dispersive spectrometric (EDS) results demonstrate that $\mathrm{Cl}_{2}$ on the spore increased with elevated peak temperature, with the majority of the $\mathrm{Cl}$ located in the shed spore coat. This study indicates that the major mechanism of spore neutralization by the synergism of $\mathrm{Cl}_{2}$ and rapid heat is chlorine reacting with the spore surface.

\section{KEYWORDS}

Bacterial spores; Neutralization; Ultrafast heating; Chlorine; Hydrogen Chloride 


\section{Introduction}

Bacterial spores have raised serious concerns in the military biodefense [1-3]. Neutralization of spores is a significant challenge since they are much more resistant than their vegetative counterparts to a variety of external stresses such as UV irradiation, extreme $\mathrm{pH}$ values, chemicals, and temperature extremes [4-6]. Studies have shown that spore longevity and resilience is correlated to physical features of spores, including a tight proteinaceous spore coat that inhibits chemicals penetration, low water content in the spore core to reduce metabolism, as well as the production of proteins for DNA stabilization (e.g. $\alpha / \beta$-type small acid soluble proteins (SASPs)) [6]. One of the primary strategies for spore neutralization is to expose them to autoclaving heat $\left(120-150{ }^{\circ} \mathrm{C}\right)$ for minutes to hours [7-9]; however, this approach is not appropriate for the large-scale neutralization of spores. To further improve the killing efficacy, aerosol based techniques are being developed to rapidly inactivate airborne bacterial spores by rapid heating ( $>200{ }^{\circ} \mathrm{C}$ within a timescale of a second) [10-16]. At this timescale, more than 3logs reduction in spore population can be achieved when the peak temperature ranges from 200 to $400{ }^{\circ} \mathrm{C}$. An analogous approach of spore inactivation by heat has been tested using heat generated from exothermic reactions of energetic materials such as aluminum-based thermites [17]. This approach is able to produce even higher peak temperatures $\left(>2200{ }^{\circ} \mathrm{C}\right)$ over a shorter period $(\sim 0.1 \mathrm{~s})$, and leads to a 7-log reduction of spore viability. Although these methods are capable of neutralize spores, an accurate and quantitative relationship of time-temperature-kill for spores is not available due to the variability in temperature distribution and the resident exposure time of these heating schemes. Nevertheless, a precise time-temperature-kill relationship is needed for predicting and ensuring a successful outcome of large-scale neutralization events. In order to improve the accuracy of measurements of the temperature 
history on spores, an alternative approach has been developed by heating spores deposited on conductive surfaces [18] that allows measurement of the transient temperature using the standard electric resistance-temperature relationships [18]. Since the transient temperature of immobilized spores can approximate that on the immobilizing surface [19], the time-temperature-kill relationship for spores can be accurately measured. Results showed that a 6-log reduction in spore counts could be achieved by rapidly heating spores to $600{ }^{\circ} \mathrm{C}$ within $50 \mathrm{~ms}$ at a heating rate of $\sim 10^{4}{ }^{\circ} \mathrm{C} / \mathrm{s}$. The neutralization mechanism was likely due to DNA damage as mutants in sspA $\operatorname{ssp} B$ are sensitized for killing [6]. Faster heating rates $\left(\sim 10^{5}{ }^{\circ} \mathrm{C} / \mathrm{s}\right)$ also improved spore neutralization, which was associated with increased structural destruction of spore coat through increased pressure of vaporization [19].

In addition to heat, another commonly used disinfection procedure for spores utilizes biocidal chemicals [20]. Commonly used biocides (antibiotics, detergents, alcohol) have little effect on spore viability [21]. In contrast, strong oxidation agents, such as chlorine, iodine, sulfur, silver, and compounds containing these elements, have demonstrated efficacy in spore inactivation [20]. Among these sporicides, $\mathrm{Cl}_{2}$ is one of the few agents that are gaseous at room temperature. The main advantage of $\mathrm{Cl}_{2}$ over other aqueous sporicides is that gas provides greater coverage, thus facilitating the neutralization of both airborne and surface-associated spores. $\mathrm{Cl}_{2}$ can directly chlorinate functional groups on macromolecules in cells to damage proteins, nucleic acids and lipids [22,23]. In addition, $\mathrm{Cl}_{2}$ can react with water to form hypochlorous acid $(\mathrm{HOCl})$ and hydrogen chloride $(\mathrm{HCl})$. Both compounds can also react with the spore to inactivate them [24][25]. 
The performance of $\mathrm{Cl}_{2}$ depends on two characteristic factors: concentration ("C") and inactivation time ("T"). The US Enivronmental Protection Agency and the water treatment industry has set the units of $\mathrm{Cl}_{2}$ concentration in parts per million (ppm) and the inactivation time in minutes [26]. In general, the "CT" product is a constant for spores of a specific Bacillus strain required to achieve a defined reduction of viability [27]. Table $1 \mathrm{~S}$ presents some documented "CT" results for different Bacillus spores [24, 26-38]. The "CT" product for a 4-log reduction in spore viability is $\sim 3 \times 10^{4} \mathrm{ppm} \cdot \mathrm{min}(\sim 100 \mathrm{mg} \cdot \mathrm{min} / \mathrm{l})$ for most of Bacillus spores when the $\mathrm{Cl}_{2}$ concentration is below $3 \times 10^{3} \mathrm{ppm}$ [26-30]. At much higher $\mathrm{Cl}_{2}$ concentrations (e.g. $7 \times 10^{6} \mathrm{ppm}$ ), this "CT" value is significantly larger than $\sim 3 \times 10^{4} \mathrm{ppm} \cdot \mathrm{min}$, and the minimum exposure time is 5 min $[24,31,32]$. In order to improve the neutralization efficiency at exposure times under a second, which according to the "CT" rule would require concentrations of $\mathrm{Cl}_{2}>10^{8} \mathrm{ppm}$ (close to that of pure $\mathrm{Cl}_{2}$ liquid). The use of these concentrations of $\mathrm{Cl}_{2}$ would be impractical as a method to safely neutralize spores [39]. To meet the guidelines set by the U.S. Food and Drug Administration (FDA) for food and drinking water processing (Code of Federal Regulations Title 21 Part 173/178) [40, 41], new approaches are in development to combine heat with 100 - 2000 $\operatorname{ppm~} \mathrm{Cl}_{2}$.

One such potent, more environment-friendly and safer approach is to synergize the neutralization of spores by $\mathrm{Cl}_{2}$ with heat. Xu et al. [42] studied the inactivation of Bacillus spores by $\mathrm{Cl}_{2}(\sim 1000 \mathrm{ppm})$ under high-temperature short-time pasteurization conditions $\left(\sim 80{ }^{\circ} \mathrm{C}\right.$, $\sim 1 \mathrm{~min}$ ), and found a viability reduction of 6-logs. Further tests using a higher temperature of 120 ${ }^{\circ} \mathrm{C}$ resulted in inactivation of spores by $6-\log$ within $16 \mathrm{~s}$, whereas it took $>30$ mins to achieve viability reduction of $6-\operatorname{logs}$ by employing either $\mathrm{Cl}_{2}$ gas $(1000 \mathrm{ppm})($ Table $\mathrm{S} 1)$ or heat $\left(120{ }^{\circ} \mathrm{C}\right)$ 
[7-9]. Based on these results, higher temperatures $\left(>200{ }^{\circ} \mathrm{C}\right)$, and diluted $\mathrm{Cl}_{2}$ gas $(<2000 \mathrm{ppm})$ synergistically inactivated bacterial spores.

In this work, we investigated the synergistic effects of ultrafast heating and $\mathrm{Cl}_{2}$ gas on the inactivation of Bacillus thuringiensis (Bt) spores. Bt spores, while closely related to Bacillus anthracis $(\mathrm{Ba})$ spores that are considered as a serious bioterrorist weapon, is not pathogenic to humans. Both Bt and Ba spores were reported to have similar sensitivity to biocides [43], so we expect the results in this study can be utilized for the neutralization of Ba spores in the future. For these studies, Bt spores were electrophoretically deposited onto a fine Pt wire [19]. By tuning the heat pulse time $\left(2 \mathrm{~ms}\right.$ and $50 \mathrm{~ms}$ ) and peak temperature (up to $\sim 1200{ }^{\circ} \mathrm{C}$ ) for the $\mathrm{Pt}$ wire, the heating rate $\left(\sim 10^{4}{ }^{\circ} \mathrm{C} / \mathrm{s}\right.$ and $\left.\sim 10^{5}{ }^{\circ} \mathrm{C} / \mathrm{s}\right)$ and time-resolved temperature for individual spores were measured [19]. Using this thermal approach, we evaluated the effect of $100 \mathrm{ppm}(0.3 \mathrm{mg} / \mathrm{l}) \mathrm{Cl}_{2}$, a concentration below the FDA safety guidelines, in combination with different peak temperatures and heating rates, on the neutralization of spores. Spore viability and morphology were assessed after these treatments by determining the viable number of colony forming units (CFU) and scanning electron microscopy (SEM). To investigate the neutralization mechanism of $\mathrm{Cl}_{2}$, spores were also heated in $\mathrm{Cl}_{2}$ gas with different relative humidities, to see the roles of $\mathrm{Cl}_{2}$ and its hydrolytic products (hydrogen chloride $(\mathrm{HCl})$ and hypochlorous acid ( $\mathrm{HOCl})$ ). Energy dispersive X-ray spectroscopy (EDS) was employed to determine the elemental changes of $\mathrm{Cl}$ and carbon (C) in spores.

\section{Materials and methods}

\subsection{Spore attachment on platinum wires}


Bt spores were sporulated in Difco Sporulation Medium (DSM) at $30{ }^{\circ} \mathrm{C}$ for $48 \mathrm{~h}$. The $250 \mathrm{ml}$ of DSM included $2 \mathrm{~g}$ Bacto nutrient broth, $2.5 \mathrm{ml} \mathrm{10 \%} \mathrm{KCl,} 0.375 \mathrm{ml} 1 \mathrm{M} \mathrm{NaOH}$ and $2.5 \mathrm{ml}$ $1.2 \% \mathrm{MgSO}_{4} \cdot 7 \mathrm{H}_{2} \mathrm{O}$. The spore concentration was enumerated by plating to be $8 \times 10^{9}$ colonyforming units per milliliter $(\mathrm{CFU} / \mathrm{ml})$. The purity of spores was found to be more than $99 \%$. Bt spores were electrophoretically immobilized onto a sterilized platinum $(\mathrm{Pt})$ wire with a diameter of $76.8 \mu \mathrm{m}$ (Omega Engineering, Inc.). The electroplating experiments were conducted in an inhouse spore deposition cell [44]. By controlling the biased deposition voltage, pulse frequency and overall charging time (from a 6340 sub-femtoamp remote sourcemeter, Keithley), we are able to prepare a uniform monolayer of $\mathrm{Bt}$ spores on the wire after 5 pulses [44]. More information of the spore deposition cell and spore coating scenarios in detail can be found in our previous studies $[19,44]$.

\subsection{Wire heating test in $\mathrm{Cl}_{2}$ gas filled chamber}

The spore coated wire was connected to an in-house built power source, working as a temperature jump probe (Fig. S1). The wire was then inserted into a gas chamber that is connected to a vacuum pump and a $\mathrm{Cl}_{2}$ gas tank (Fig. S1). Prior to the pulse heating of the wire, the chamber was emptied by vacuum and replenish with the appropriate concentrations of $\mathrm{Cl}_{2}$ gas. For evaluating the effect of relative humidity $(\mathrm{RH})$ of $\mathrm{Cl}_{2}$ gas, the chamber is also connected to a water bubbler that can supply water vapor into the chamber. RH was monitored using an attached humidity meter. A defined thermal history for spores on wire during the heating period was measured through the dynamic electric resistance-temperature relationship for Pt (Callendar-Van Dusen equation [18]). The peak temperature $\left(\sim 200{ }^{\circ} \mathrm{C}\right.$ to $\left.\sim 700{ }^{\circ} \mathrm{C}\right)$ and the heating rate $\left(\sim 10^{4}{ }^{\circ} \mathrm{C} / \mathrm{s}\right.$ 
to $\sim 10^{5}{ }^{\circ} \mathrm{C} / \mathrm{s}$ ) can be precisely controlled by tuning the applied voltage and the pulse time ( $2 \mathrm{~ms}$ to $50 \mathrm{~ms}$ ). The temperature-time profile for spores in the cooled region was calculated according to an energy balance equation which was dominated by the heat conduction. It is estimated that the cooling time scale is between $\sim 300 \mathrm{~ms}$ and $\sim 500 \mathrm{~ms}$ [19]. The detailed description of the transient temperature measurement on spores can be found in our previous study [19].

Since $\mathrm{Cl}_{2}$ will be hydrolyzed to produce $\mathrm{HCl}$ and $\mathrm{HOCl}$ in the presence of humidity, as a comparison the effect of $\mathrm{HCl}$ was also investigated by exposing spores to $\mathrm{HCl}$ gas released from a beaker of $36 \%$ wt. $\mathrm{HCl}$ solution inside the chamber. The solution was extracted from the chamber after $\sim 10$ mins, when the equilibrium vapor pressure of $\mathrm{HCl}$ inside the chamber was achieved ( 1800 ppm) (calculated based on a known partial vapor pressure of $\mathrm{HCl}$ as $0.18 \mathrm{kPa}$ [45]). Then the chamber was vacuumed to $1 / 18 \mathrm{~atm}$, followed by air inflation $(40 \% \mathrm{RH})$ back to $1 \mathrm{~atm}$. The final concentration of $\mathrm{HCl}$ inside chamber was kept as $\sim 100 \mathrm{ppm}(40 \% \mathrm{RH})$. The procedure of heating spores in this case is similar to that in the $\mathrm{Cl}_{2}$ case above.

\subsection{Determination of colony forming units}

The viable spores after various heat and $\mathrm{Cl}_{2}$ treatments were enumerated by determining CFUs. Spore-coated wires were completely submerged in $1 \mathrm{ml}$ of Lysogeny Broth (LB) media (10 g tryptone, $5 \mathrm{~g}$ yeast extract and $5 \mathrm{~g} \mathrm{NaCl}$ per liter) and placed on a shaker at the $37{ }^{\circ} \mathrm{C}$ for three hours to allow for the germination and detachment of viable spores from the wire surface. After incubation, samples were serially diluted and plated on LB agar plates to count viable CFUs. 


\subsection{Characterization of morphology of spores}

The surface morphology of spores with or without treatment of $\mathrm{Cl}_{2}$ and rapid heat was investigated by SEM (Hitachi S-4700) using an accelerating voltage of $5 \mathrm{kV}$. Prior to imaging, the spore-coated wire was attached to stubs and then sputtered with gold/palladium alloy.

\subsection{Characterization of hydrocarbon and chlorine contents inside spores}

Quantitative EDS X-ray microanalysis using SEM was employed to analyze the elemental contents (carbon, chlorine and calcium) inside spores. Since calcium will not escape from spores by evaporation (boiling point at $\sim 1500{ }^{\circ} \mathrm{C}$ ) during the rapid heating in our temperature regimen $\left(<700{ }^{\circ} \mathrm{C}\right)$, the detected calcium content was used as a control to measure the relative $\mathrm{Cl}$ and $\mathrm{C}$ contents. The tests were conducted in the line scan mode by detecting the elemental intensity along a line drawn across one spore. The ratio of mass fractions of $\mathrm{Cl} / \mathrm{Ca}$ or $\mathrm{C} / \mathrm{Ca}$ was calculated by comparing the integrated intensities of $\mathrm{Cl} / \mathrm{Ca}$ or $\mathrm{C} / \mathrm{Ca}$ along the line, respectively. For spores with their coats detached, a line was across either the cracked coat or the exposed core, to analyze the distribution of elemental masses in both compartments. Statistical analyses are based on a spore population of $\sim 10$.

\section{Results and discussion}

\subsection{Spore viability heated at two ramp rates in air and in $\mathrm{Cl}_{2}$}


The neat effect of fast heating on the viability of Bt spores in air was determined and the relationship between peak temperature and spore viability was plotted in Fig. 1. The viability data fit a sigmoidal model [46] as:

$$
S=\frac{1}{1+\exp \left(k\left(T-T_{c}\right)\right)}
$$

where $S$ is the survival ratio of spores $\left(\mathrm{CFU}_{\text {final }} / \mathrm{CFU}_{\text {initial }}\right), T$ is the peak temperature, $T_{c}$ is the critical peak temperature to induce viability reduction by half, and $k$ is the heat resistance parameter. The fitted values of $T_{c}$ and $k$ are listed in Table 1 . Compared to $T_{c}\left(405{ }^{\circ} \mathrm{C}\right)$ at the temperature rate of $\sim 10^{4}{ }^{\circ} \mathrm{C} / \mathrm{s}, T_{c}$ at $\sim 10{ }^{\circ} \mathrm{C} / \mathrm{s}$ decreases to $230{ }^{\circ} \mathrm{C}$. In addition, a reduction of 6logs was achieved at the peak temperatures of $400{ }^{\circ} \mathrm{C}$ and $600{ }^{\circ} \mathrm{C}$ at $\sim 10^{5}{ }^{\circ} \mathrm{C} / \mathrm{s}$ and $\sim 10^{4}{ }^{\circ} \mathrm{C} / \mathrm{s}$, respectively. These neutralization data for Bt spores resemble those for Bs spores in our previous studies [19], indicating that the faster heating rate of $\sim 10^{5}{ }^{\circ} \mathrm{C} / \mathrm{s}$ is able to effectively decrease the peak temperature required for spore neutralization when compared to the heating rate of $\sim 10^{4}$ ${ }^{\circ} \mathrm{C} / \mathrm{s}$. In addition, the $k$ value of the neutralization curve at the higher heating rate $\left(\sim 10^{5}{ }^{\circ} \mathrm{C} / \mathrm{s}\right)$ was larger than that at the lower heating rate $\left(\sim 10^{4}{ }^{\circ} \mathrm{C} / \mathrm{s}\right)$, indicating that $\mathrm{Bt}$ spores are more sensitive to higher heating rates. These results show a better neutralization effect for Bt spores by higher heating rates and higher peak temperatures.

The effect of $\mathrm{Cl}_{2}$ gas and rapid heat was evaluated for their ability to synergistically neutralize Bt spores. The resistance of $\mathrm{Bt}$ spores to $\mathrm{Cl}_{2}$ gas at room temperature was first assessed. After 15 minutes of exposure, spore viability was not affected when exposed to $1 \mathrm{ppm}(0.003 \mathrm{mg} / \mathrm{L})$ to $100 \mathrm{ppm}(0.3 \mathrm{mg} / \mathrm{L})$ of $\mathrm{Cl}_{2}$ (Fig. S2), whereas spores were completely neutralized by $1000 \mathrm{ppm}$ of $\mathrm{Cl}_{2}$. We used $100 \mathrm{ppm}$ of $\mathrm{Cl}_{2}$ for the rest of this study since this concentration did not neutralize Bt spores in the absence of heat and is within the FDA guidelines $(200-2000 \mathrm{ppm})$ 
[41, 42]. Heating to $250{ }^{\circ} \mathrm{C}$ at $\sim 10^{4}{ }^{\circ} \mathrm{C} / \mathrm{s}$, and $170{ }^{\circ} \mathrm{C}$ at $\sim 10^{5}{ }^{\circ} \mathrm{C} / \mathrm{s}$ (Fig. 1) reduced spore viability. Compared to the viability results by heat treatment alone, the critical peak temperatures $T_{c}$ decrease by $150{ }^{\circ} \mathrm{C}$ and $50{ }^{\circ} \mathrm{C}$ at heating rates of $\sim 10^{4}{ }^{\circ} \mathrm{C} / \mathrm{s}$ and $\sim 10^{5}{ }^{\circ} \mathrm{C} / \mathrm{s}$, respectively (Table 1 ). In addition, a 6-log viability reduction was achieved at lower temperatures of $300{ }^{\circ} \mathrm{C}$ at $\sim 10^{5}{ }^{\circ} \mathrm{C} / \mathrm{s}$, and $450{ }^{\circ} \mathrm{C}$ at $\sim 10^{4}{ }^{\circ} \mathrm{C} / \mathrm{s}$. These results show a synergistic effect of rapid heat pulses and $\mathrm{Cl}_{2}$ gas in the neutralization of Bt spores in both heating schemes. It should be noted that the $k$ values for the neutralization curves of spores treated with $\mathrm{Cl}_{2}$ and without $\mathrm{Cl}_{2}$ are similar at the same heating rate ( $>0.1$ for $50 \mathrm{~ms}$ pulse and $<0.1$ for $2 \mathrm{~ms}$ pulse), indicating that the temperature sensitivity of spore neutralization is primarily controlled by the heating rate instead of the addition of $\mathrm{Cl}_{2}$.

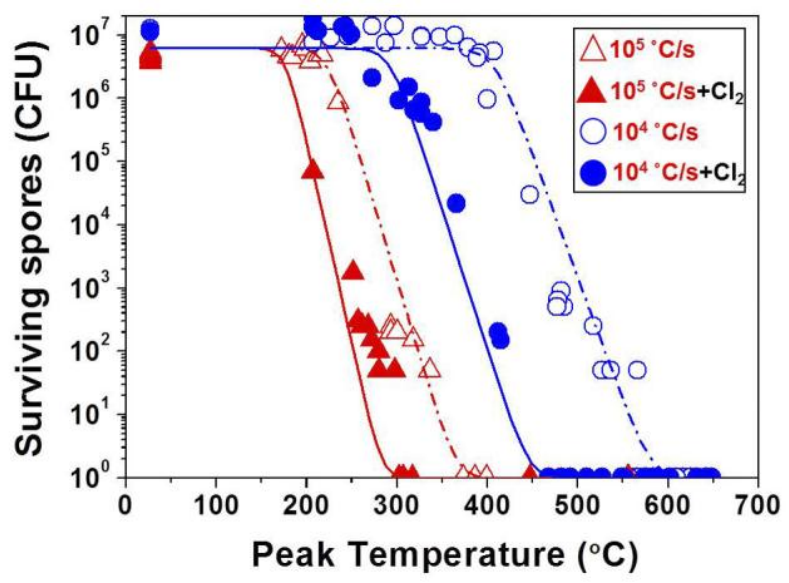

Fig. 1. Survival curves of Bt spores versus peak temperature for $2 \mathrm{~ms}\left(\sim 10^{5}{ }^{\circ} \mathrm{C} / \mathrm{s}\right)$ and $50 \mathrm{~ms}$ $\left(\sim 10^{4}{ }^{\circ} \mathrm{C} / \mathrm{s}\right)$ heat pulses, and with or without the presence of $\mathrm{Cl}_{2}(100 \mathrm{ppm})$. The relative humidity was kept at $40 \%$.

\section{Table 1.}

Fitting results for the variables in Eq. 1. 


\begin{tabular}{|c|c|c|c|c|}
\hline Heating conditions & $\mathrm{Cl}_{2}(+,-)$ & RH & $k\left({ }^{\circ} \mathrm{C}^{-1}\right)$ & $T_{c}\left({ }^{\circ} \mathrm{C}\right)$ \\
\hline $50 \mathrm{~ms}$ heating pulse $\left(\sim 10^{4}{ }^{\circ} \mathrm{C} / \mathrm{s}\right)$ & - & $40 \%$ & 0.090 & 407 \\
\hline $50 \mathrm{~ms}$ heating pulse $\left(\sim 10^{4}{ }^{\circ} \mathrm{C} / \mathrm{s}\right)$ & + & $40 \%$ & 0.065 & 252 \\
\hline $50 \mathrm{~ms}$ heating pulse $\left(\sim 10^{4}{ }^{\circ} \mathrm{C} / \mathrm{s}\right)$ & + & $0 \%$ & 0.065 & 352 \\
\hline $50 \mathrm{~ms}$ heating pulse $\left(\sim 10^{4}{ }^{\circ} \mathrm{C} / \mathrm{s}\right)$ & + & $100 \%$ & 0.083 & 180 \\
\hline $2 \mathrm{~ms}$ heating pulse $\left(\sim 10^{5} \mathrm{C} / \mathrm{s}\right)$ & - & $40 \%$ & 0.109 & 232 \\
\hline $2 \mathrm{~ms}$ heating pulse $\left(\sim 10^{5} \mathrm{C} / \mathrm{s}\right)$ & + & $40 \%$ & 0.146 & 176 \\
\hline $2 \mathrm{~ms}$ heating pulse $\left(\sim 10^{5}{ }^{\circ} \mathrm{C} / \mathrm{s}\right)$ & + & $0 \%$ & 0.136 & 247 \\
\hline $2 \mathrm{~ms}$ heating pulse $\left(\sim 10^{5} \mathrm{C} / \mathrm{s}\right)$ & + & $100 \%$ & 0.131 & 177 \\
\hline
\end{tabular}

\subsection{Spore viability heated in $\mathrm{Cl}_{2}$ gas of different $R H$ at two ramp rates}

To understand the mechanism of spore inactivation by $\mathrm{Cl}_{2}$, different humidities were supplemented to the $100 \mathrm{ppm}$ of $\mathrm{Cl}_{2}$ in the gas chamber used for heat inactivation of Bt spores. The gas chamber for the results described in Section 3.1 has a relative humidity of $\sim 40 \%$, similar to that of ambient air. At $\sim 10^{4}{ }^{\circ} \mathrm{C} / \mathrm{s}$, the critical peak temperature for spores heated in $\mathrm{dry} \mathrm{Cl}_{2}(0 \%$ $\mathrm{RH})$ is $100{ }^{\circ} \mathrm{C}$ higher than that in moderately humidified $\mathrm{Cl}_{2}(40 \% \mathrm{RH})$, whereas the critical peak temperature for spores heated in moist $\mathrm{Cl}_{2}(100 \% \mathrm{RH})$ is $70{ }^{\circ} \mathrm{C}$ lower (Table 1). These results show that the $T_{c}$ is reduced as the humidity of $\mathrm{Cl}_{2}$ increases indicating that the synergistic effect of $\mathrm{Cl}_{2}$ and rapid heat is potentiated by high humidity.

When the heating rate for Bt spores increases to $\sim 10^{5}{ }^{\circ} \mathrm{C} / \mathrm{s}, T_{c}$ increased for $\mathrm{Bt}$ spores treated with dry $\mathrm{Cl}_{2}(0 \% \mathrm{RH})$ (Fig. 2B), similar to spores heated at $\sim 10^{4}{ }^{\circ} \mathrm{C} / \mathrm{s}$ heating rate (Fig. $\left.2 \mathrm{~A}\right)$. In contrast, moderately humidified $\mathrm{Cl}_{2}(40 \% \mathrm{RH})$, and moist $\mathrm{Cl}_{2}(100 \% \mathrm{RH})$ resulted in similar $T_{c}$, 
$176{ }^{\circ} \mathrm{C}$ and $177{ }^{\circ} \mathrm{C}$, respectively (Table 1). These $\sim 10^{5}{ }^{\circ} \mathrm{C} / \mathrm{s}$ results are distinct from those at $\sim 10^{4}$ ${ }^{\circ} \mathrm{C} / \mathrm{s}$ since there is minimal change of spore neutralization when $\mathrm{RH}$ of $\mathrm{Cl}_{2}$ increases from $40 \%$ to $100 \%$ (Fig. 2B). Thus, the synergistic effect of $\mathrm{Cl}_{2}$ in different humidities at $\sim 10^{5}{ }^{\circ} \mathrm{C} / \mathrm{s}$ is reduced as compared to the lower heating rates of $\sim 10^{4}{ }^{\circ} \mathrm{C} / \mathrm{s}$. The reduction in the effect of humidity can be in part attributed to the reduced change in $T_{c}\left(\sim 60{ }^{\circ} \mathrm{C}\right)$ for spores heated in air and in $\mathrm{Cl}_{2}$ at $\sim 10^{5}{ }^{\circ} \mathrm{C} / \mathrm{s}$, which is much smaller than that $\left(\sim 160{ }^{\circ} \mathrm{C}\right)$ at $\sim 10^{4}{ }^{\circ} \mathrm{C} / \mathrm{s}$ (Fig. 1 and Table 1). To evaluate the heating-rate-dependent synergistic effects of $\mathrm{Cl}_{2}$, we assessed the changes to $\mathrm{Bt}$ spore morphology and composition in response to $\mathrm{Cl}_{2}$ and rapid heat.
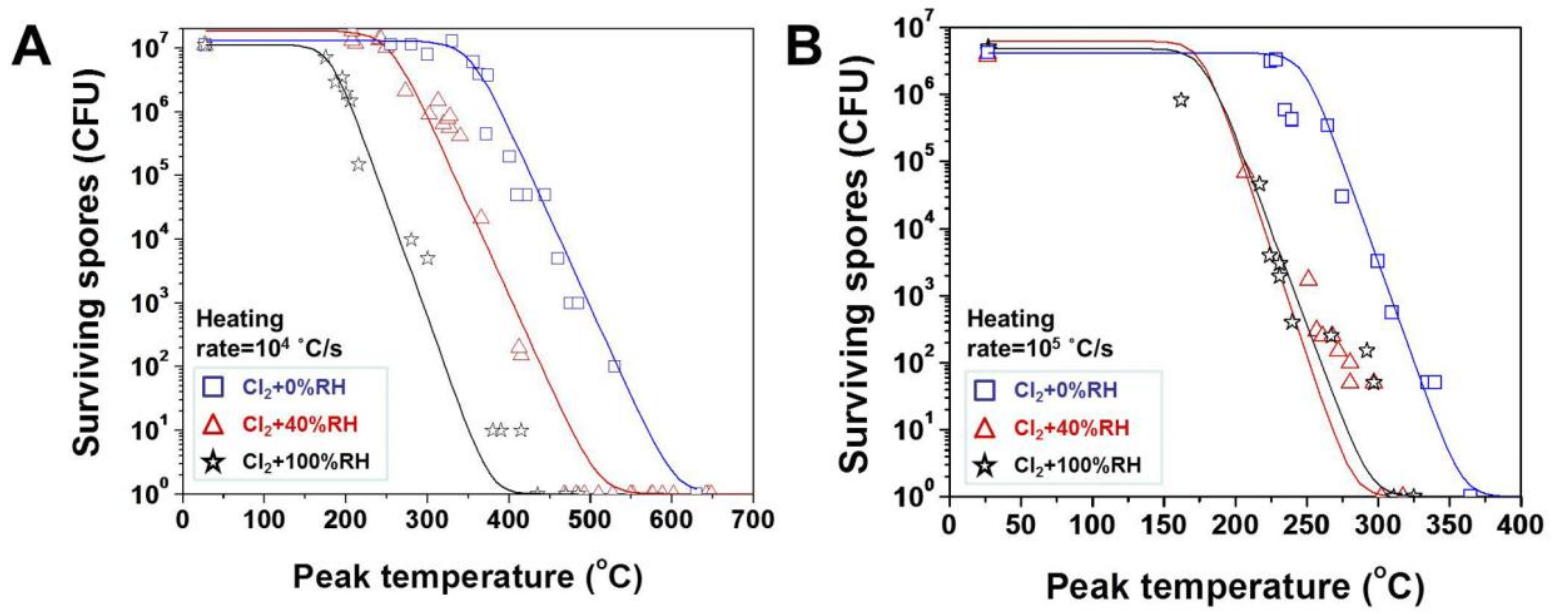

Fig. 2. Survival curves of Bt spores versus peak temperature for $50 \mathrm{~ms}\left(\sim 10^{4}{ }^{\circ} \mathrm{C} / \mathrm{s}\right)(\mathrm{A})$ and $2 \mathrm{~ms}$ $\left(\sim 10^{5}{ }^{\circ} \mathrm{C} / \mathrm{s}\right)(\mathrm{B})$ heat pulses. The blue, red, and black curves fit the survival of spores in response to $\mathrm{Cl}_{2}$ and heat at $0 \%, 40 \%$, and $100 \%$ relative humidities.

\subsection{Spore morphology after treatment of rapid heat and $\mathrm{Cl}_{2}$ gas}

$\mathrm{Cl}_{2}$ vapor in the chamber surrounds the immobilized spores and is in contact with the surface of the spores. The effect of $\mathrm{Cl}_{2}$ and heat on $\mathrm{Bt}$ spores was assessed by scanning electron 
microscopy (SEM). The unheated spores had a general dimension of $1.5 \mu \mathrm{m}$ (longitudinal) times $1.0 \mu \mathrm{m}$ (transversal) with wrinkly protrusions along their surfaces (Fig. 3A and Fig. S2B). In the absence of heat, treatment with $\mathrm{Cl}_{2}$ gas up to $1000 \mathrm{ppm}$, which was sufficient to completely inactivate Bt spores, did not alter spore morphology (Fig. S2C). The relationship between spore morphology and peak temperature was investigated first for Bt spores exposed to the higher heating rates $\left(\sim 10^{5}{ }^{\circ} \mathrm{C} / \mathrm{s}\right)$. The spore coat remains unaffected when heated to a peak temperature of $200{ }^{\circ} \mathrm{C}$ at $\sim 10^{5}{ }^{\circ} \mathrm{C} / \mathrm{s}$ (Fig. 3B). When heated to $300{ }^{\circ} \mathrm{C}$ at $\sim 10^{5}{ }^{\circ} \mathrm{C} / \mathrm{s}$, the spore surface started to melt and the surface protrusions were reduced (Fig. 3C). Further increases in the peak temperature to $\sim 400{ }^{\circ} \mathrm{C}$ at $\sim 10^{5}{ }^{\circ} \mathrm{C} / \mathrm{s}$ caused the surfaces of $\mathrm{Bt}$ spores to melt (Fig. 3D). At higher peak temperatures of $>450{ }^{\circ} \mathrm{C}$, the surface coat was completely melted and only the underlying core remained (Fig. 3E and 3F). When $100 \mathrm{ppm} \mathrm{Cl}_{2}$ was used, Bt spores were morphological indistinguishable from the spores treated by heat alone when the peak temperature is below $\sim 400$ ${ }^{\circ} \mathrm{C}$ (Fig. 3G-3I and Fig. 3A-3C). However, a distinct morphology emerged after $\sim 400{ }^{\circ} \mathrm{C}$ when additional surface cracks were formed and the spore coat were detached from the underlying core (Fig. 3J-3K) in contrast to the spore coat melting in the absence of $\mathrm{Cl}_{2}$. The disintegration of spore coat was further deteriorated when the humidity of $\mathrm{Cl}_{2}$ increased to $100 \%$ at $400{ }^{\circ} \mathrm{C}$ (Fig. S3), suggesting that the effect of $\mathrm{Cl}_{2}$ on the destruction of spore coat is associated with $\mathrm{RH}$. Together these results indicate that $\mathrm{Cl}_{2}$ acts on the surface of the spore to alter the fluidity of the spore coat.

The SEM images of Bt spores at a lower ramp rate of $\sim 10^{4}{ }^{\circ} \mathrm{C} / \mathrm{s}$ revealed similar morphological changes (Fig. 4A-4D) as that at a higher ramp rate of $\sim 10^{5}{ }^{\circ} \mathrm{C} / \mathrm{s}$ (Fig. 3A-3D). Bt spores started to melt at the peak temperature of $\sim 300{ }^{\circ} \mathrm{C}$, and completely melted at the peak temperature of $\sim 400{ }^{\circ} \mathrm{C}$. The addition of $\mathrm{Cl}_{2}$ did not alter Bt spore morphology (Fig. 4E-4H) 
compared to the effect of heat alone (Fig. 4A-4D). These results indicate that the morphological changes were determined by peak temperatures at $\sim 10^{4}{ }^{\circ} \mathrm{C} / \mathrm{s}$.

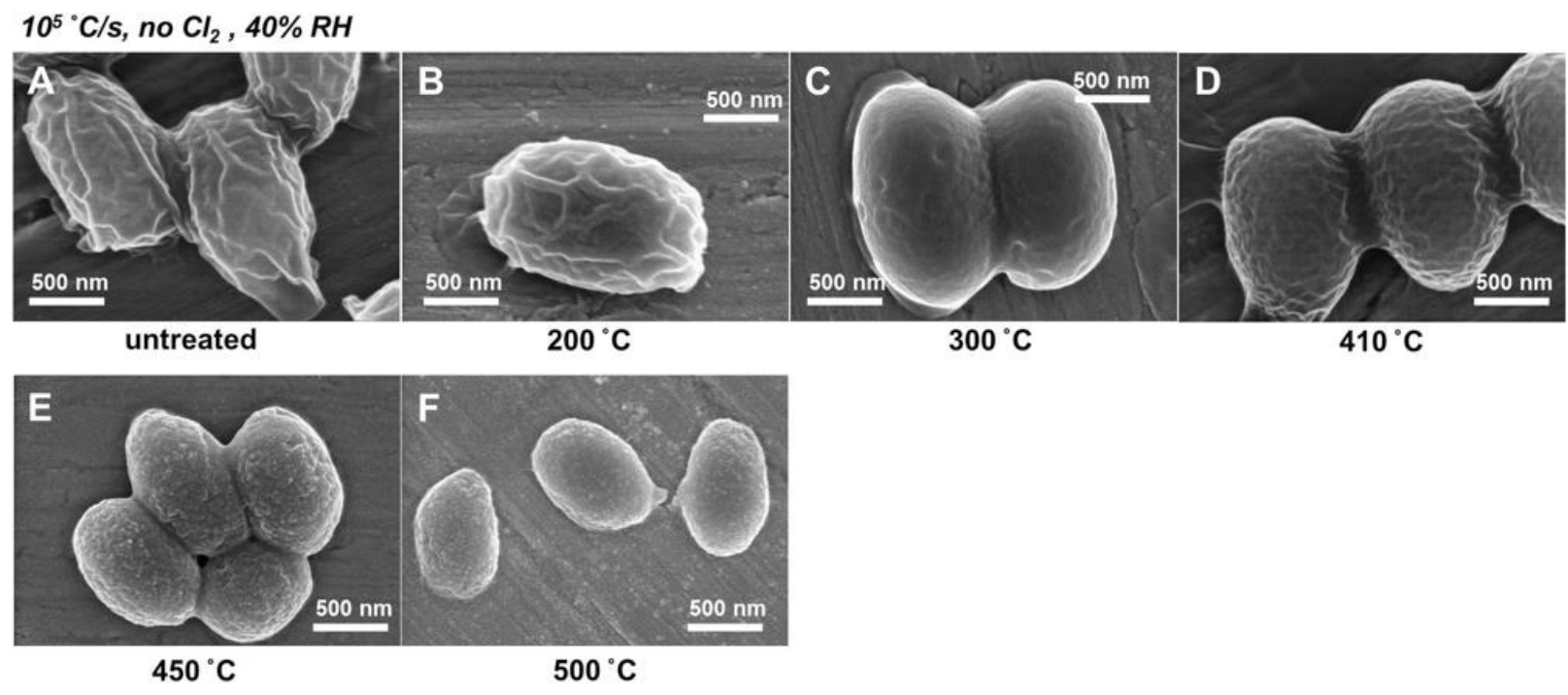

$10^{5} \mathrm{C} / \mathrm{s}$, add $\mathrm{Cl}_{2}, 40 \% \mathrm{RH}$

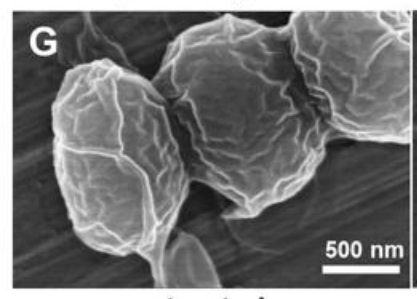

untreated

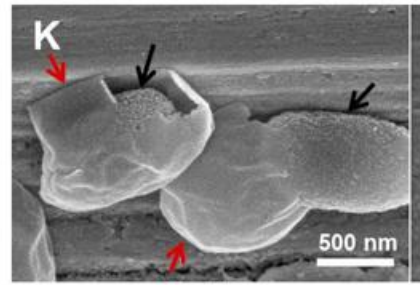

$450{ }^{\circ} \mathrm{C}$

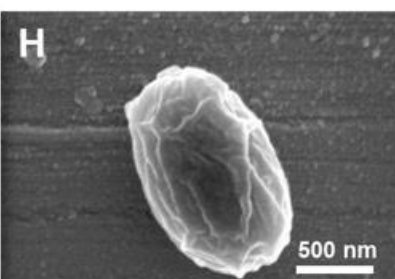

$190^{\circ} \mathrm{C}$

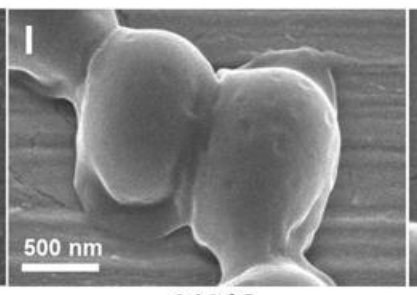

$310^{\circ} \mathrm{C}$

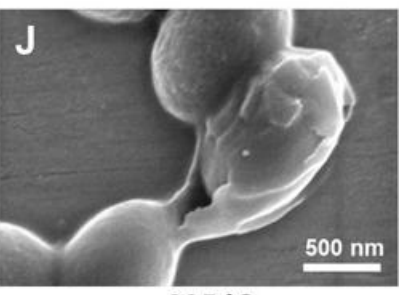

$385^{\circ} \mathrm{C}$

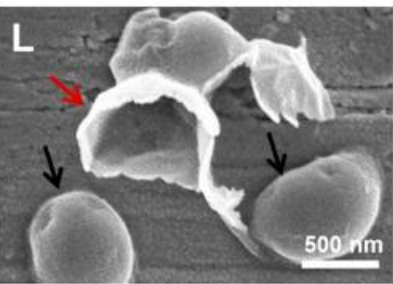

$500^{\circ} \mathrm{C}$

Fig. 3. Spore morphologies when heated to different peak temperatures at $\sim 10^{5}{ }^{\circ} \mathrm{C} / \mathrm{s}$ without (A$F)$ or with $(G-L)$ the presence of $\mathrm{Cl}_{2}$. The relative humidity was kept at $40 \%$. The red arrows and the black arrows in image $4 K$ and $4 L$ designate detached spore coats and exposed spore cores, respectively. 


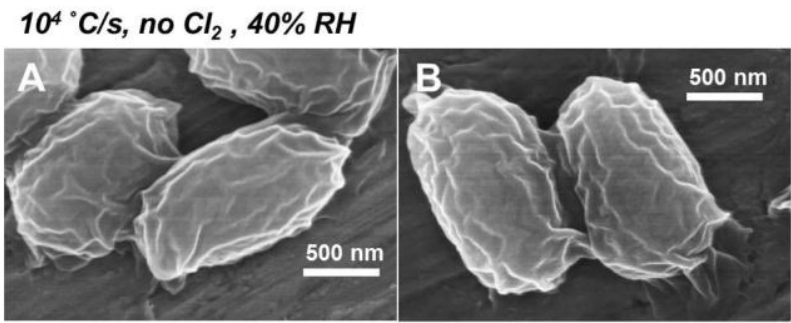

untreated

$145^{\circ} \mathrm{C}$

$10^{\circ} \mathrm{C} / \mathrm{s}$, add $\mathrm{Cl}_{2}, 40 \% \mathrm{RH}$

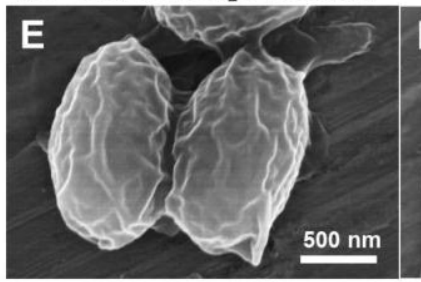

untreated

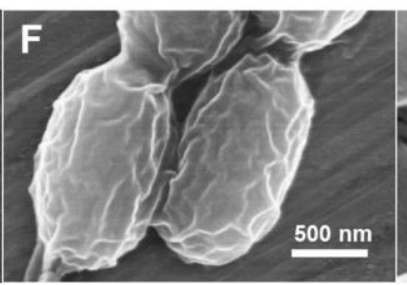

$185^{\circ} \mathrm{C}$

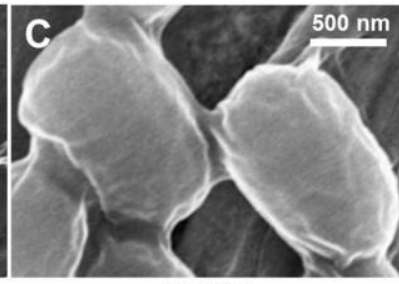

$325^{\circ} \mathrm{C}$

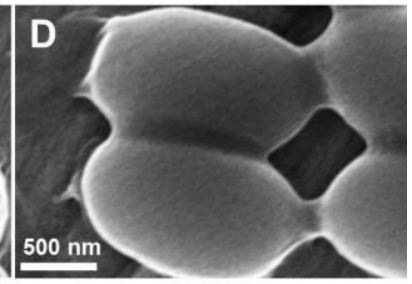

$425^{\circ} \mathrm{C}$

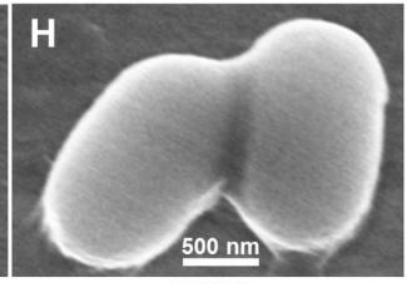

$425^{\circ} \mathrm{C}$

Fig. 4. Spore morphologies when heated to different peak temperatures at $\sim 10^{4}{ }^{\circ} \mathrm{C} / \mathrm{s}$ without (AD) or with $(E-H)$ the presence of $\mathrm{Cl}_{2}$. The relative humidity is was kept at $40 \%$.

\subsection{Changes in $\mathrm{C}$ and $\mathrm{Cl}$ contents inside Bt spores exposed to rapid heat and $\mathrm{Cl}_{2}$}

To evaluate the effect of $\mathrm{Cl}_{2}$ on spores, the mass fractions of chlorine $(\mathrm{Cl})$ and carbon $(\mathrm{C})$ within spores treated by different heating schemes were measured using EDS. Calcium was used in these experiments as a standard since the calcium content inside spores will not change within our experimental temperature range $\left(<700{ }^{\circ} \mathrm{C}\right)($ Fig. 5). The $\mathrm{Cl}$ content of the spores exposed to $\mathrm{Cl}_{2}$ at room temperature was low indicating that $\mathrm{Cl}_{2}$ gas does not react readily with the spores at ambient temperatures. The $\mathrm{Cl}$ content was increased as the peak temperature rose at $\sim 10^{4}{ }^{\circ} \mathrm{C} / \mathrm{s}$, with the mass concentration of $\mathrm{Cl}$ for spores heated to $400{ }^{\circ} \mathrm{C} \sim 50$ folds higher than that at room temperature. At the higher ramp rate of $\sim 10^{5}{ }^{\circ} \mathrm{C} / \mathrm{s}$, a similar trend of increased $\mathrm{Cl}$ content was observed for spores exposed to higher peak temperature. At each temperature, the $\mathrm{Cl}$ content of spores exposed to $\sim 10^{5}{ }^{\circ} \mathrm{C} / \mathrm{s}$ heating rate was higher than spores exposed to the $\sim 10^{4}{ }^{\circ} \mathrm{C} / \mathrm{s}$ heating rate (Fig. 5B). These results demonstrate that both peak temperature and heating rate enhance the 
reaction of $\mathrm{Cl}_{2}$ with the spores. To determine the location on the spore that is reacting with $\mathrm{Cl}_{2}$, we took advantage of the SEM observation that the spore coat detaches from the core when heated to $500{ }^{\circ} \mathrm{C}$ at $\sim 10^{5}{ }^{\circ} \mathrm{C} / \mathrm{s}$ heating rate in the presence of $\mathrm{Cl}_{2}$. EDS of the detached spore coat revealed that there is a $\mathrm{Cl} / \mathrm{Ca}$ ratio of 0.335 as compared to $0.005 \mathrm{Cl} / \mathrm{Ca}$ ratio in the core (Fig $5 \mathrm{~B}$ ). The 70-fold increase in $\mathrm{Cl}$ concentration in the spore coat indicates that $\mathrm{Cl}_{2}$ is reacting primarily with the surface of the spores during the rapid heating event.

Since SEM images reveal that the spores disintegrated at high temperatures, the carbon content within spores was evaluated. Spores heated either in air or in $\mathrm{Cl}_{2}$ at $\sim 10^{4}{ }^{\circ} \mathrm{C} / \mathrm{s}$ did not lose carbon content (Fig. 5C). Given that the spore coat was not completely melted until $400{ }^{\circ} \mathrm{C}$ (Fig. 4), this result shows that the intact spore surface inhibits the release of volatile carbons. When rapidly heated at $\sim 10^{5}{ }^{\circ} \mathrm{C} / \mathrm{s}$, the $\mathrm{C}$ content in spores decreased starting at $300{ }^{\circ} \mathrm{C}$ and $400{ }^{\circ} \mathrm{C}$ for $\mathrm{Bt}$ spores heated in $\mathrm{Cl}_{2}$ and in air, respectively (Fig. 5D). The decrease in carbon content correlates with the SEM images of revealing damage to the $\mathrm{Bt}$ spores heated both in air and in $\mathrm{Cl}_{2}$ at $400{ }^{\circ} \mathrm{C}$ (Fig. $3 \mathrm{D}$ and $3 \mathrm{~J})$. In addition, at $300{ }^{\circ} \mathrm{C}$ the remaining $\mathrm{C}$ content for spores heated in $100 \% \mathrm{RH} \mathrm{Cl}_{2}$ is $40 \%$ less than that for spores heated in $0 \% \mathrm{RH} \mathrm{Cl}_{2}$ (Fig. S4), indicating that the carbon release increases at a higher $\mathrm{RH}$. This is consistent with the fact that heating in the presence of $\mathrm{Cl}_{2}$ gas at a higher RH induces more damage to the spore surface (Fig. S3). The carbon release occurred at peak temperatures that are higher than the corresponding $T_{c}$ for Bt spores, indicating that release of volatile carbons is not the primary factor for spore neutralization at both temperature rates. 

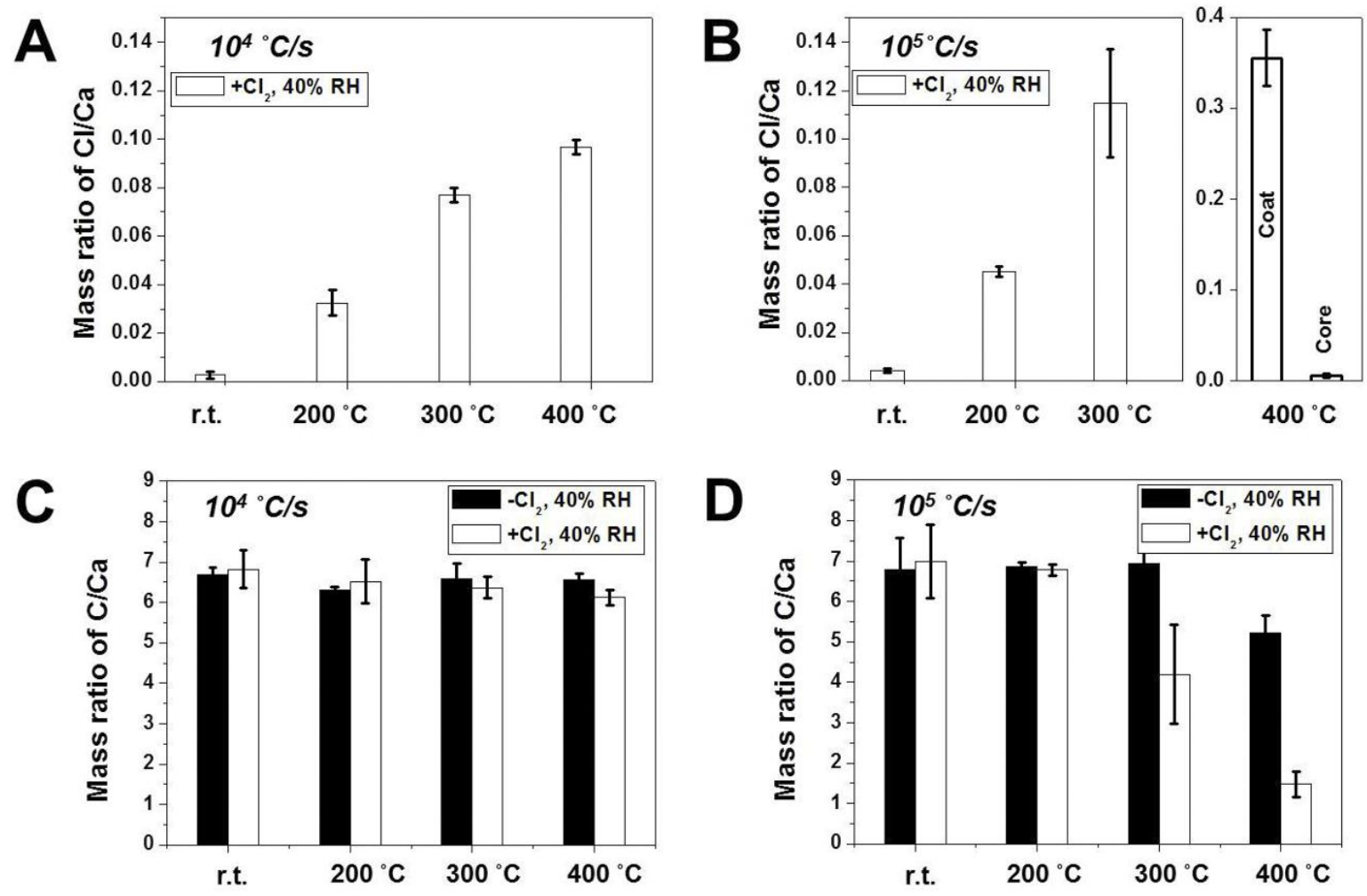

Fig. 5. EDS (energy dispersive spectroscopic) results on the chlorine ( $A$ and $B)$ and carbon $(C$ and D) mass contents in spores heated at $\sim 10^{4}{ }^{\circ} \mathrm{C} / \mathrm{s}$ ( $A$ and $C$ ) and $\sim 10^{5}{ }^{\circ} \mathrm{C} / \mathrm{s}$ ( $B$ and $\left.D\right)$ rates. The right side of the graph $(B)$ shows the relative mass contents of $C l$ in the coat and core of spores heated to $400{ }^{\circ} \mathrm{C}$ at $\sim 10^{5}{ }^{\circ} \mathrm{C} / \mathrm{s}$. The constant content of $\mathrm{Ca}$ inside spores is taken as a control and normalized to 1 . Both the relative contents of $\mathrm{Cl}$ and $\mathrm{C}$ are presented as the mass ratios of $\mathrm{Cl} / \mathrm{Ca}$ and $C / C a$, respectively.

\subsection{Spore viability heated at $\sim 10^{4}{ }^{\circ} \mathrm{C} / \mathrm{s}$ in $\mathrm{HCl}$}

The viability, morphological and EDS results for spores heated in $\mathrm{Cl}_{2}$ (Figs. 1-5) indicate that humidity enables to improve the spore neutralization by $\mathrm{Cl}_{2}$ and rapid heating. The reason for this spore neutralization improvement can be attributed to the generation of new biocidal products from $\mathrm{Cl}_{2}$ hydrolysis, such as $\mathrm{HCl}$ and $\mathrm{HOCl}$. As a control, the spore neutralization in $\mathrm{HCl}$ of the same concentration as $\mathrm{Cl}_{2}(100 \mathrm{ppm})$ was also investigated. At a relative humidity of 
$40 \%$, Fig. S5 shows that unheated spores in the presence of $\mathrm{HCl}$ gas remained their viability. However, spores heated at $\sim 10^{4}{ }^{\circ} \mathrm{C} / \mathrm{s}$ in $\mathrm{HCl}$ were killed by $>\sim 4$ logs at the peak temperature of $\sim 400{ }^{\circ} \mathrm{C}$, which is similar with that in $\mathrm{Cl}_{2}(\sim 4$ logs, see Fig. 1). This result indicates that $\mathrm{HCl}$ is comparably efficient to synergize rapid heat in neutralizing spores

\section{Discussion}

\subsection{Neutralization of $\mathrm{Bt} v s$ Bs spores at two heating rates without $\mathrm{Cl}_{2}$}

Our results (Fig. 1 and Table 1) show that the neutralization of Bt spores by rapid heat treatment alone is determined by the peak temperature and heating rate. The critical peak temperatures for Bt spores heated at $\sim 10^{4}{ }^{\circ} \mathrm{C} / \mathrm{s}$ and at $\sim 10^{5}{ }^{\circ} \mathrm{C} / \mathrm{s}$ are $407{ }^{\circ} \mathrm{C}$ and $232{ }^{\circ} \mathrm{C}$, respectively (Table 1). Previously, we have also studied the neutralization of Bs spores under similar heating schemes [19]. The critical peak temperatures for Bs spores heated at these two ramp rates are $20-30{ }^{\circ} \mathrm{C}$ lower, indicating that $\mathrm{Bs}$ spores are more sensitive to rapid heat than $\mathrm{Bt}$ spores. SEM observations of Bs and Bt spores heated at $\sim 10^{4}{ }^{\circ} \mathrm{C} / \mathrm{s}$ show that spore coats melt at $410{ }^{\circ} \mathrm{C}[19]$ and $425{ }^{\circ} \mathrm{C}$, respectively. When heated at $\sim 10^{5}{ }^{\circ} \mathrm{C} / \mathrm{s}$, the coats of Bs spores started to generate visible fissures at a peak temperature of $300{ }^{\circ} \mathrm{C}$ [19]. In contrast, at the same heating rate and temperature, there are only very small pin holes observed on the surface of Bt spores (Fig. 3C). Together, these results indicate that the spore coat of $\mathrm{Bt}$ is less temperature sensitive, which corresponds to the fact that Bt spores possess a higher $T_{c}$ to rapid heat.

The previously reported neutralization mechanisms for Bs spores depend on the heating rate [19]. At $\sim 10^{4}{ }^{\circ} \mathrm{C} / \mathrm{s}$, inactivation is likely due to the thermal damage to DNA since mutants 
lacking small acid-soluble proteins that protect the DNA within spore showed enhanced sensitivity to heat. At $\sim 10^{5}{ }^{\circ} \mathrm{C} / \mathrm{s}$, the spore coat was compromised by elevated internal vapor pressurization from rapid heating [19]. Since neutralization of Bt and Bs was increased at the elevated $\sim 10^{5}{ }^{\circ} \mathrm{C} / \mathrm{s}$ heating rate, Bt spores likely undergo the same neutralization mechanism as Bs spores. This is supported by the similarity of SEM morphological changes in response to heating at $\sim 10^{4}{ }^{\circ} \mathrm{C} / \mathrm{s}$. Furthermore, heating of $\mathrm{Bt}$ at $\sim 10^{5}{ }^{\circ} \mathrm{C} / \mathrm{s}$ to $300{ }^{\circ} \mathrm{C}$ caused the emergence of holes on the surface of the spores indicating that the Bt spores experienced a similar pressurization event as the Bs spores (Fig. 3C). Although the size of the holes on the surface of Bt spores are reduced in size, heating of Bt spores at $\sim 10^{5}{ }^{\circ} \mathrm{C} / \mathrm{s}$ to $>400^{\circ} \mathrm{C}$ in the presence of $\mathrm{Cl}_{2}$ led to the entire spore coat detaching from the underlying core. This phenomenon also supports the idea that internal pressure lead to rupture of the fixed spore coat. Results presented here and in earlier studies demonstrate that Bs and Bt spores undergoing rapid heat treatments can be neutralized through two different mechanisms depending on the rate of heating.

\subsection{The interaction of $\mathrm{Cl}_{2}$ and spores}

$\mathrm{Cl}_{2}$ synergizes with rapid heat pulses to inactivate spores at both the $\sim 10^{4}{ }^{\circ} \mathrm{C} / \mathrm{s}$ and $\sim 10^{5}{ }^{\circ} \mathrm{C} / \mathrm{s}$ heating rates (Fig. 1). Our results thus raise two central questions: 1) which form of $\mathrm{Cl}_{2}$ is enhancing the synergistic killing of $\mathrm{Bt}$ spores? 2) where is this form of $\mathrm{Cl}_{2}$ acting on the spore? The mechanism by which $\mathrm{Cl}_{2}$ synergizes with heat pulses is not completely understood. $\mathrm{Cl}_{2}$ gas, in addition to being a potent oxidizer, can form chemical bonds with numerous organic and nonorganic molecules [23]. Our study has revealed several important findings regarding the form of $\mathrm{Cl}_{2}$ that is enhancing synergistic killing with heat. First, increased water vapor concentrations in 
the chamber enhanced the potency of $\mathrm{Cl}_{2}$ (Fig. 2). $\mathrm{Cl}_{2}$ can readily react with $\mathrm{H}_{2} \mathrm{O}$ to form $\mathrm{HCl}$ and $\mathrm{HOCl}$ [23]. Since $\mathrm{Cl}_{2}$ synergizes with heat pulses minimally in the absence of humidity (Fig. 2), the compounds that actively enhance neutralization are likely $\mathrm{HCl}$ or $\mathrm{HOCl}$ rather than $\mathrm{Cl}_{2}$ gas. We have estimated that it only requires seconds to reach the reaction equilibrium for $\mathrm{Cl}_{2} / \mathrm{H}_{2} \mathrm{O}$ (see the detailed calculation in the supplemental information), which is much shorter than our experimental time scale (minutes). Additional evidence for the higher neutralization activity of $\mathrm{HCl} / \mathrm{HOCl}$ than $\mathrm{Cl}_{2}$ is that when the peak temperature increases from $100{ }^{\circ} \mathrm{C}$ to $300{ }^{\circ} \mathrm{C}$, the molar ratio of $\mathrm{Cl}_{2} / \mathrm{HCl}$ decreases from $\sim 4$ to $\sim 0.13$ due to a biased reaction equilibrium from $\mathrm{Cl}_{2}+\mathrm{H}_{2} \mathrm{O}$ towards $\mathrm{HCl}+\mathrm{HOCl}$ at high temperatures (according to CEA (NASA Chemical Equilibrium with Applications) calculations [47] given that the initial concentration of $\mathrm{Cl}_{2}$ is $4.2 \times 10^{-3} \mathrm{~mol} / \mathrm{m}^{3}$ with a $\mathrm{RH}$ of $40 \%$ ). Correspondingly, the spore viability reduced significantly as the temperature increased suggesting that $\mathrm{HCl} / \mathrm{HOCl}$ is more effective in spore neutralization.

The target of $\mathrm{Cl}_{2}$ inactivation on the spore is also an area of interest since this can reveal vulnerabilities of Bacillus spores that can be exploited in biodefense. The EDS data on $\mathrm{Cl}$ support the idea that the heat treatment with $\mathrm{Cl}_{2}$ leads to an accumulation of $\mathrm{Cl}$ on the detached spore coat (Fig. 5) indicating the chlorine is interacting primarily with the surface of the spore during the heating pulse. As being said, the two major biocidal agents that interact with spore coat are $\mathrm{HCl}$ and $\mathrm{HOCl}$, which have unique chemical properties. $\mathrm{HCl}$ is a strong acid that can act to denature proteins on the spore coat [48-50]. In contrast, $\mathrm{HOCl}$ can react with organic molecules leading to chlorine covalently attached to the molecules on and in the spores [23]. Therefore, the $\mathrm{Cl}$ detected in the spore coat by EDS is either deposited as $\mathrm{Cl}^{-}$anion from deprotonated $\mathrm{HCl}$ or covalently attached through chemical reactions of $\mathrm{HOCl}$ to cellular organic molecules. The effect of $\mathrm{HCl}$ on $\mathrm{Bt}$ spores was tested by heating spores at $\sim 10^{4}{ }^{\circ} \mathrm{C} / \mathrm{s}$ in the 
presence of only $\mathrm{HCl}$ gas. Results show that $\mathrm{HCl}$ also synergized with heat to neutralize spore similarly to the heat treatment with $\mathrm{Cl}_{2}$ with $40 \% \mathrm{RH}$ (Fig. 1 and Fig. S5). These results suggest that $\mathrm{HCl}$ produced by the reaction between $\mathrm{Cl}_{2}$ and water vapor is one of the active biocidal agent at these heating rates and peak temperatures. Since $\mathrm{HOCl}$ is known to form covalent bonds with organic molecules, we believe that both $\mathrm{HCl}$ and $\mathrm{HOCl}$ promote synergistic killing with rapid heat pulses. Future studies of the synergistic effect of $\mathrm{HOCl}$ with rapid heat pulse would provide direct evidence to support the active compound that inactivates spores. Furthermore, future identification of the spore coat protein(s) that are covalently modified by chlorine will reveal the bacterial target(s) that confers sensitivity.

\subsection{Synergistic neutralization mechanisms for $\mathrm{Bt}$ spores by rapid heat and $\mathrm{Cl}_{2}$}

There are two potential mechanisms for the observed synergistic effect in spore neutralization between rapid heat and $\mathrm{Cl}_{2}: 1$ ). A chemical mechanism in which heat activates $\mathrm{Cl}_{2}$ to become a more potent biocide or 2). A biological mechanism in which $\mathrm{Cl}_{2}$ and heat damage different targets in the spores to enhance inactivation. Although these two potential mechanisms are not mutually exclusive, the synergistic effect of heat and $\mathrm{Cl}_{2}$ is at least in part due to the heat pulse overcoming the activation energy of reactions between chlorine and the spore. The EDS data shows that exposure to $\mathrm{Cl}_{2}$ alone does not increase $\mathrm{Cl}$ content in the spore. Only when heated does the $\mathrm{Cl}$ content of the spore increase, supporting the idea that heat enhances the reactivity of $\mathrm{Cl}_{2}$. In addition to the increase in $\mathrm{Cl}_{2}$ reactivity, the biological targets of heat and $\mathrm{Cl}_{2}$ act on different parts of the spore. Heat pulses at $\sim 10^{4}{ }^{\circ} \mathrm{C} / \mathrm{s}$ damage DNA [19], whereas $\mathrm{Cl}_{2}$ targets the spore coat. The combination of coat damage and DNA damage can act synergistically neutralize 
spores. Support for this model of inactivation is that heat pulses at $\sim 10^{5}{ }^{\circ} \mathrm{C} / \mathrm{s}$, which inactivates spores primarily through physical damage of the spore coat [19], synergizes minimally with $\mathrm{Cl}_{2}$. Thus damaging different targets within the spores, rather than the same target, enhances synergistic neutralization.

Another feature of the synergism of $\mathrm{Cl}_{2}$ with heat pulses is that this effect occurs at peak temperatures and heating rate far below what was required to fix and detach the spore coat (Fig 5). An open question is whether the effect observed at the higher peak temperature $\left(>500^{\circ} \mathrm{C}\right)$ and high heating rate $\left(\sim 10^{5}{ }^{\circ} \mathrm{C} / \mathrm{s}\right)$ applies to the lower peak temperature and heating rates, which nonetheless synergize with $\mathrm{Cl}_{2}$ to neutralize $\mathrm{Bt}$ spores. Despite the lack of visual changes of the spores as detected by SEM at peak temperatures of under $300{ }^{\circ} \mathrm{C}$, the $\mathrm{Cl}$ content on the spore increases as detected by EDS. One interpretation of these results is that heat pulses between 200$300{ }^{\circ} \mathrm{C}$ activate $\mathrm{Cl}_{2}$ to interact with spores. Even this lower level of chlorine modification of the spore surface can negatively impact the function of the spore coat and increase spore inactivation.

\section{Conclusion}

Surface immobilized Bt spores subjected to the synergistic effects of ultrafast heating and biocidal chlorine gas were characterized by several observations including changes in viability, morphology, and composition. At the heating rates of $\sim 10^{4}{ }^{\circ} \mathrm{C} / \mathrm{s}$, the critical peak temperatures for spore neutralization were reduced from $407{ }^{\circ} \mathrm{C}$ in air to $252{ }^{\circ} \mathrm{C}$ when exposed to $100 \mathrm{ppm} \mathrm{Cl}_{2}$. At the higher heating rates of $\sim 10^{5} \mathrm{C} / \mathrm{s}$, the critical peak temperatures for spore neutralization are decreased from $232{ }^{\circ} \mathrm{C}$ in air to $176{ }^{\circ} \mathrm{C}$ when exposed to $100 \mathrm{ppm} \mathrm{Cl}_{2} . \mathrm{Cl}_{2}$ synergizes with rapid heat pulse to enhance spore neutralization. Additional experiments revealed that the synergistic effect of $\mathrm{Cl}_{2}$ and heat was increased in high humidity, whereas the synergistic effect decreased in low humidity. $\mathrm{Cl}_{2}$ can react with water to generate $\mathrm{HCl}$ and $\mathrm{HOCl}$, which in turn react with the spore. Despite enhancing neutralization, $\mathrm{Cl}_{2}$ and heat pulses under $300{ }^{\circ} \mathrm{C}$ did not alter the 
morphology of the spores. However, treatment of spores at peak temperatures $>450{ }^{\circ} \mathrm{C}$ at $\sim 10^{5}$ ${ }^{\circ} \mathrm{C} / \mathrm{s}$ caused the spore coat to detach completely from the endospore. EDS results showed that $\mathrm{Cl}$ is present in heated spores and the majority of the chlorine is present in detached spore coat indicating that chlorine is acting on the surface of the spores. Our results suggest that the spore surface damage caused by $\mathrm{Cl}_{2}$, via $\mathrm{HOCl}$ and/or $\mathrm{HCl}$, is the major mechanism in enhanced spore neutralization by rapid heat.

\section{Acknowledgements}

This work was funded by a grant from DOD/DTRA (BRBAA08-Per5-H-2-0065). We thank Mr. Tim Maugel in the Laboratory for Biological Ultrastructure at the University of Maryland, College Park for his assistance in SEM imaging.

\section{References}

[1] E. Nadasi, T. Varjas, I. Prantner, V. Virag, I. Ember, Bioterrorism: Warfare of the 21st century, Gene Ther. Mol. Biol. 11 (2007) 315-320.

[2] Y. Gilbert, C. Duchaine, Bioaerosols in industrial environments: a review, Can. J. Civ. Eng. 36 (2009) 1873-1886.

[3] V. Kummer, W.R. Thiel, Bioaerosols - Sources and control measures, Int. J. Hyg. Environ Health. 211 (2008) 299-307.

[4] G.W. Gould, History of science - spores Lewis B Perry memorial lecture 2005, J. Appl. Microbiol. 101 (2006) 507-513.

[5] W.L. Nicholson, N. Munakata, G. Horneck, H.J. Melosh, P. Setlow. Resistance of Bacillus endospores to extreme terrestrial and extraterrestrial environments, Microbiol. Mol. Biol. Rev. 64 (2000) 548-572. 
[6] P. Setlow, Spores of Bacillus subtilis: their resistance to and killing by radiation, heat and chemicals, J. Appl. Microbiol. 101 (2006) 514-525.

[7] R. Conesa, P.M. Periago, A. Esnoz, A. Lopez, A. Palop, Prediction of Bacillus subtilis spore survival after a combined non-isothermal-isothermal heat treatment, Eur. Food Res. Technol. 217 (2003) 319-324.

[8] O. Couvert, S. Gaillard, N. Savy, P. Mafart, I. Leguerinel, Survival curves of heated bacterial spores: effect of environmental factors on Weibull parameters, Int. J. Food Microbiol. 101 (2005) 73-81.

[9] W.H. Coleman, D. Chen, Y-Q. Li, A.E. Cowan, P. Setlow P, How moist heat kills spores of Bacillus subtilis, J. Bacteriol. 189 (2007) 8458-8466.

[10] S.D. Gates, A.D. McCartt, P. Lappas, J.B. Jeffries, R.K. Hanson, L.A. Hokama, K.E. Mortelmans, Bacillus endospores resistance to gas dynamic heating, J. Appl. Microbiol. 109 (2010) 1591-1598.

[11] S.D. Gates, A.D. McCartt, J.B. Jeffries, R.K. Hanson, L.A. Hokama, K.E. Mortelmans, Extension of Bacillus endospore gas dynamic heating studies to multiple species and test conditions, J. Appl. Microbiol. 111 (2011) 925-931.

[12] S.A. Grinshpun, A. Adhikari, C. Li, T. Reponen, M. Yermakov, M. Schoenitz, E. Dreizin, M. Trunov, S. Mohan, Thermal inactivation of airborne viable Bacillus subtilis spores by shortterm exposure in axially heated air flow, J. Aerosol Sci. 41 (2010) 352-363.

[13] S.A. Grinshpun, C. Li, A. Adhikari, M. Yermakov, T. Reponen, M. Schoenitz, E. Dreizin, V. Hoffmann, M. Trunov, Method for studying survival of airborne viable microorganisms in combustion environments: development and evaluation, Aerosol Air Qual. Res. 10 (2010) 414424. 
[14] E. Johansson, A. Adhikari, T. Reponen, M. Yermakov, S.A. Grinshpun, Association between increased DNA mutational frequency and thermal inactivation of aerosolized Bacillus spores exposed to dry heat, Aerosol Sci. Technol. 45 (2011) 376-381.

[15] J.H. Jung, J.E. Lee, S.S. Kim, Thermal effects on bacterial bioaerosols in continuous air flow, Sci. Total Environ. 407 (2009) 4723-4730.

[16] Y.H. Lee, B.U. Lee, Inactivation of airborne E. coli and B. subtilis bioaerosols utilizing thermal energy, J. Microbiol. Biotechnol. 16 (2006) 1684-1689.

[17] B-D. Lee, R. Thiruvengadathan, S. Puttaswamy, B.M. Smith, K. Gangopadhyay, S. Gangopadhyay, S. Sengupta, Ultra-rapid elimination of biofilms via the combustion of a nanoenergetic coating, BMC Biotechnol. 13 (2013) 30.

[18] P.R.N. Childs, Practical Temperature Measurement, Butterworth Heinemann, London, UK, 2001.

[19] W. Zhou, M.W. Orr, G. Jian, S.K. Watt, V.T. Lee, M.R. Zachariah, Inactivation of bacterial spores subjected to sub-second thermal stress, Chem. Eng. J. 279 (2015) 578-588.

[20] G. McDonnell, A.D. Russell, Antiseptics and disinfectants: activity, action, and resistance, Clin. Microbiol. Rev. 12 (1999) 147-179.

[21] A. Fraise, Currently available sporicides for use in healthcare, and their limitations, J. Hosp. Infect. 77 (2011) 210-212.

[22] M.M. Coombs, J.F. Danielli, Chlorination of proteins as a method of increasing their opacity in the electron microscope, Nature. 183 (1959) 1257-1258.

[23] M. Deborde, U. von Gunten, Reactions of chlorine with inorganic and organic compounds during water treatment - kinetics and mechanisms: a critical review, Water Res. 42 (2008) 13-51. 
[24] G.A. DeQueiroz, D.F. Day, Disinfection of Bacillus subtilis spore-contaminated surface materials with a sodium hypochlorite and a hydrogen peroxide-based sanitizer, Lett. Appl. Microbiol. 46 (2008) 176-180.

[25] S.B. Young, P. Setlow, Mechanisms of killing of Bacillus subtilis spores by hypochlorite and chlorine dioxide, Appl. Environ. Microbiol. 95 (2003) 54-67.

[26] L.J. Rose, E.W. Rice, B. Jensen, R. Murga, A. Peterson, R.M. Donlan, M.J. Arduino, Chlorine inactivation of bacterial bioterrorism agents, Appl. Environ. Microbiol. 71 (2005) 566568.

[27] A.R. Brazis, J.E. Leslie, P.W. Kabler, R.L. Woodward, The inactivation of spores of Bacillus globigii and Bacillus anthracis by free available chlorine, Appl. Microbiol. 6 (1958) $338-342$.

[28] E.W. Rice, N.J. Adcock, M. Sivaganesan, L.J. Rose, Inactivation of spores of Bacillus anthracis Sterne, Bacillus cereus, and Bacillus thuringiensis subsp. israelensis by chlorination, Appl. Environ. Microbiol. 71 (2005) 5587-5589.

[29] G.M. Fair, J.C. Morris, S.L. Chang, The dynamics of chlorination, J. New Engl. Water Works Assoc. 61 (1947) 285-301.

[30] A.A. Hosni, W.T. Shane, J.G. Szabo, P.L. Bishop, The disinfection efficacy of chlorine and chlorine dioxide as disinfectants of Bacillus globigii, a surrogate for Bacillus anthracis, in water networks: a comparative study, Can. J. Civ. Eng. 36 (2009) 732-737.

[31] J. Szabo, S. Minamyer, Decomtamination of biological agents from drinking water infrastructure: a literature review and summary, Environ. Int. 72 (2014) 124-128. 
[32] A.C. Kreske, J-H. Ryu, C.A. Pettigrew, L.R. Beuchat, Lethality of chlorine, chlorine dioxide, and a commercial produce sanitizer to Bacillus cereus and Pseudomonas in a liquid detergent, on stainless steel, and in biofilm, J. Food Prot. 69 (2006) 2621-2634.

[33] L.V. Venczel, M. Arrowood, M. Hurd, M.D. Sobsey, Inactivation of Cryptosporidium parvum oocysts and Clostridium perfringens spores by a mixed-oxidant disinfectant and by free chlorine, Appl. Environ. Microbiol. 63 (1997) 1598-1601.

[34] C.H. Johnson, M.M. Marshall, L.A. DeMaria, J.M. Moffet, D.G. Korich, Chlorine inactivation of spores of Encephalitozoon spp., Appl. Environ. Microbiol. 69 (2003) 1325-1326.

[35] H. Son, M. Cho, H. Chung, S. Choi, J. Yoon, Bactericidal activity of mixed oxidants: comparison with free chlorine, J. Ind. Eng. Chem. 10 (2004) 705-709.

[36] J. Perez, S. Springthorpe, S.A. Sattar, Activity of selected oxidizing microbiocides against the spores of Clostridium difficile: relevance to environmental control, Am. J. Infect. Control. 33 (2005) 320-325.

[37] D.E. John, C.N. Haas, N. Nwachuku, C.P. Gerba, Chlorine and ozone disinfection of Encephalitozoon intestinalis spores, Water Res. 39 (2005) 2369-2375.

[38] R.M.S. Thorn, G.M. Robinson, D.M. Reynolds, Comparative antimicrobial activities of aerosolized sodium hypochlorite, chlorine dioxide, and electrochemically activated solutions evaluated using a novel standardized assay, Antimicrob. Agents Chemother. 57 (2013) 22162225 .

[39] http://emergency.cdc.gov/agent/chlorine/basics/facts.asp 
[40] http://www.accessdata.fda.gov/scripts/cdrh/cfdocs/cfCFR/CFRSearch.cfm?CFRPart=173

[41] http://www.accessdata.fda.gov/scripts/cdrh/cfdocs/cfcfr/CFRSearch.cfm?CFRPart=178

[42] S. Xu, T.P. Labuza, F. Diez-Gonzalez, Inactivation of Bacillus anthracis spores by a combination of biocides and heating under high-temperature short-time pasteurization conditions, Appl. Environ. Microbiol. 74 (2008) 3336-3341.

[43] J-L. Sagripanti, M. Carrera, J. Insalaco, M. Ziemski, J. Rogers, R. Zandomeni, Virulent spores of Bacillus anthracis and other Bacillus species deposited on solid surfaces have similar sensitivity to chemical decontaminants, J. Appl. Microbiol. 102 (2007) 11-21.

[44] W. Zhou, S.K. Watt, D-H. Tsai, V.T. Lee, M.R. Zachariah, Quantitative attachment and detachment of bacterial spores from fine wires through continuous and pulsed DC electrophoretic deposition, J. Phys. Chem. B. 117 (2013) 1738-1745.

[45] M. Massucci, S.L. Clegg, P. Brimblecombe, Equilibrium partial pressures, thermodynamic properties of aqueous and solid phases, and $\mathrm{Cl}_{2}$ production from aqueous $\mathrm{HCl}$ and $\mathrm{HNO}_{3}$ and their mixtures, J. Phys. Chem. A. 103 (1999) 4209-4226.

[46] J.N. Junior, P.R. de Massaguer, Thermal death kinetics of B. stearothermophilus spores in sugarcane must, J. Food Proc. Eng. 30 (2007) 625-639.

[47] http://www.grc.nasa.gov/WWW/CEAWeb/ceaHome.htm

[48] L.R. Wyatt, W.M. Waites, The effect of chlorine on spores of Clostridium bifermentans, Bacillus subtilis and Bacillus cereus, J. Gen. Microbiol. 89 (1975) 337-344. 
[49] B. Setlow, C.A. Loshon, P.C. Genest, A.E. Cowan, C. Setlow, P. Setlow, Mechanisms of killing spores of Bacillus subtilis by acid, alkali and ethanol, J. Appl. Microbiol. 92 (2002) 362375.

[50] M. Cho, J-H. Kim, J. Yoon, Investigating synergism during sequential inactivation of Bacillus subtilis spores with several disinfectants, Water Res. 40 (2006) 2911-2920. 